\title{
IAMJ
}

INTERNATIONAL

AYURVEDIC

MEDICAL JOURNAL

Research Article

ISSN: 23205091

Impact Factor: 5.344

\section{PHYSICOCHEMICAL AND PHYTOCHEMICAL ANALYSIS OF Mangifera indica linn.( AAMRA KERNEL )}

\author{
Pooja Dogra ${ }^{1}$, A. Rama Murthy ${ }^{2}$, Sumit Nathani ${ }^{3}$, Neha Prajapati ${ }^{4}$ \\ ${ }^{1}$ MD Scholar, Department of Dravyaguna, National Institute of Ayurveda, Rajasthan, India \\ ${ }^{2}$ Professor, Department of Dravyaguna, National Institute of Ayurveda, Rajasthan, India \\ ${ }^{3}$ Assistant Professor, Department of Dravyaguna, National Institute of Ayurveda, Rajasthan, India \\ ${ }^{4} \mathrm{MD}$ Scholar, Department of Dravyaguna, National Institute of Ayurveda, Rajasthan, India
}

Corresponding Author: 06poojadogra@gmail.com

\section{https://doi.org/ $10.46607 /$ iamj05p4052020}

(Published online: July 2020)

Open Access

(C) International Ayurvedic Medical Journal, India 2020

Article Received: 01/07/2020 - Peer Reviewed:21/08/2020 - Accepted for Publication: 21/08/2020

\section{Check for updates}

\footnotetext{
ABSTRACT

Introduction: Mangifera Indica Linn., Anacardiaceae family, is a large evergreen tree of tropical and subtropical regions of the world. Mango kernel can be used as a potential source for functional food ingredients, animal feeds, antimicrobial compounds and cosmetic due to its high quality of fat and protein as well as high levels of natural antioxidants.

Aim: The aim of the present study was to evaluate the physicochemical and phytochemical analysis of Mangifera Indica Linn.

Methods Aamra Kernel were collected, cleaned, dried and powdered. Aqueous and alcoholic extracts of Aamra kernel were analyzed for physicochemical and phytochemical constituents. The study was conducted as per the guidelines of Ayurvedic pharmacopeia of India.

Results: The result of physicochemical parameters (moisture content: $10.2 \%$, total ash: $2.12 \%$, acid insoluble ash: $0.3 \%$, water soluble ash: $1.42 \%$, aqueous extractive value: $14.67 \%$ and alcoholic extractive value $12.98 \%$ ). The phytochemical studies revealed the presence of active constituents, carbohydrates, amino acid, steroids, proteins, saponins, alkaloids, glycosides, tannins in aqueous and alcoholic extracts.
} 
Conclusion: All studies standardization parameters like physicochemical and phytochemical screening parameters provide the knowledge in the identification, authentication of kernel of Mangifera Indica Linn. Hence it is concluded that this drug supposed to be great beneficial and boon for our society.

Keywords: Mangifera Indica Linn., physicochemical and phytochemical.

\section{INTRODUCTION}

Ayurveda is one of the most ancient system of life, health and care. Indian Science of Medicine has the largest collection of medicinal plants. Mangifera Indica Linn (Aamra) commonly used plant in Ayurvedic medicine. Mangifera Indica Linn., Anacardiaceae family, is a large evergreen tree of tropical and subtropical regions of the world. Commonly cultivated for its fruits throughout the country. Its population and importance can easily be realized by the fact that it is often referred as "King of Fruit in the tropical World" This herb has its own medicinal importance since it plays a significant role in the treatment of various diseases. Various synonyms compiled from various ancient texts are given as Aamra (it provides good health and strength. Choot (It possesses plenty of juice), Rasala (Its taste is very much palatable and lovable), Sahkara (Appears beautiful with its flowers and fruits), Atisaurabha (Flowers have pleasant intoxicating aroma), Amlaphala (sour when unripe $)^{1}$ Different vernacular names are Mango tree, spring tree (Eng), Am, Amchur (Hindi), Amri, Ambo (Gujrati), Maa, Mankai (Tamil) Mamidi, Mavi (Telgu), Am (Oriya) Kernel kernel has sweet, acrid, astringent, refrigerant, cooling, Haemostatic, antehelmintic, constipating, diarrhea, dysentery and vomiting properties. ${ }^{2}$ Its parts used for medicinal purpose are root, bark, leaf, flower, fruit and kernel kernel. ${ }^{3}$

\section{Taxonomical Classification:}

$\begin{array}{ll}\text { Kingdom } & : \text { Plantae } \\ \text { Class } & \text { : Mangoliopsida } \\ \text { Phylum } & : \text { Mangoliophyta } \\ \text { Order } & \text { : Sapindales } \\ \text { Family } & : \text { Anacardiaceae } \\ \text { Genus } & \text { : Mangifera } \\ \text { Species } & : \text { Indica }\end{array}$

Botanical Description: ${ }^{4}$

* Habit \& Habitat
* It is a large, evergreen tree with widely spreading branches and thick dark grey bark and about 10-45 $m$ in height.

* Leaves - Are crowed at the end of the branches and are alternate, simple, linear-oblong elliptic or ovate lanceolate, acute or acuminate and 15-30 in number.

* Flowers - Are greenish -yellow and odourus in terminal panicle, which are about $25 \mathrm{~cm}$ long.

* Flowering - In March- April

* Kernels - Are large and compressed with planoconvex cotyledons.

* Fruits - Juicy stone fruits, compressed and fibrous. Materials and Methods:

Collection of Plant Material: Aamra Kernel (dried) was taken from Jaipur crude raw drug market after proper identification. The plant material was identified and authenticated for their botanical identify from Raw material Herbarium and Museum, Delhi (RHMD) of national institute of science communication and information resources (NISCAIR) Delhi. Aamra Mangifera indica Linn. was authentified under the reference number NISCAIR/ RHMD/consult/2019/3484-85-2.

\section{Physico- Chemical Parameters:}

Determination of Moisture Content: ${ }^{5}$ Moisture content was determined by placing weighed samples of $5 \mathrm{gm}$ of each drug in oven at $105^{\circ}$ for 5 hours and calculated weight of the sample for every 30 minute until the weight of the samples were constant, no variation of weight are recorded. This sample was allowed to cool at room temperature in a desiccator for 1 hour before weighing.

\section{Determination of Ash Value: 6}

Total Ash: Weighed accurately 5 gm of powdered drug sample in the Silica crucible. The drug was spread evenly into a thin layer. This crucible was placed in a muffle furnace and ignited at a temperature of $450^{\circ} \mathrm{C}$ 
for about 6 hours or more until the ash was totally free from Carbon. The crucible containing the ash was allowed to be cooled in desiccators and subsequently weighed to constant weight.

Determination of Water-Soluble Ash: Boiled the total ash for 5 minutes with $25 \mathrm{ml}$ of water; collect the insoluble matter in a Gooch's Crucible or on an ash less filter paper, Washed with hot water and ignited for 15 minutes at a temperature not exceeding $4500 \mathrm{C}$. Subtracted the weight of the insoluble matter from the weight of the ash; the difference in weight represents the water soluble ash. Percentage of water-soluble ash was calculated with reference to the air-dried drug.

Determination of Acid Insoluble Ash: Boiled the to- $>$ tal ash with $25 \mathrm{ml}$ of $2 \mathrm{M}$ Hydrochloric acid for 5 minutes. Collected the insoluble matter in a Gooch crucible or on an ash less filter paper, wash with hot water, ignite, cool in a desiccator and weigh. Percentage of acid insoluble ash was calculated with reference to the air-dried drug.

\section{Determination of Extractive Values: ${ }^{7}$ Determination of Alcohol Soluble Extractive:}

Macerate $5 \mathrm{gm}$ of the air-dried drug coarsely powdered of Mangifera Indica Linn with $100 \mathrm{ml}$ of Alcohol of the specified strength in a closed flask for twenty-four hours. Shaking frequently for six hours and allowed to stand for eighteen hours. Filter rapidly, taking precautions against loss of solvent, evaporate $25 \mathrm{ml}$ of the filtrate to dryness in tared flat-bottomed shallow dish and dry at $105^{\circ}$, to constant weight and weigh. Calculate the percentage of alcohol-soluble extractive with reference to the air-dried drug.

\section{Determination of Water-Soluble Extractive:}

Macerate $5 \mathrm{gm}$ of the air-dried drug, coarsely powdered of Mangifera Indica, with $100 \mathrm{ml}$ of water of the specified strength in a closed flask for twenty-four hours. Shaking frequently for six hours and allowed to stand for eighteen hours. Filter rapidly, taking precautions against loss of solvent, evaporate $25 \mathrm{ml}$ of the filtrate to dryness in tared flat-bottomed shallow dish and dry at $105^{\circ}$, to constant weight and weigh. Calculate the percentage of alcohol-soluble extractive with reference to the air-dried drug.
Preliminary Phytochemical Analysis: ${ }^{8}$ The phytochemical analysis of this plant was performed for the detection of active constituents

i. e. carbohydrates, amino acid, steroids, alkaloids, protein, saponin, tannin and glycosides.

\section{Tests of Carbohydrates:}

Molisch's Test: $2 \mathrm{ml}$ of test Solution was taken in a test tube and $2 \mathrm{ml}$ of the Molisch's reagent was added and shaken carefully and then about $1 \mathrm{ml}$. of conc. $\mathrm{H}_{2} \mathrm{SO}_{4}$ is poured from side of the test tube and allowed to stand for one 1 minute. A Purple colour ring at the junction of the two layers if formed indicated the presence of Carbohydrate.

Benedict's test: It is used for reducing sugars and composed of mainly Copper sulphate and sodium hydroxide. To the $4 \mathrm{ml}$ of aqueous solution of drug, $1 \mathrm{ml}$ of Benedict's solution was added and heated almost to boiling. Formation of green, yellow, orange, red or brown colour in order of increasing concentrations of simple sugar in the test solution, due to formation of cuprous oxide

Fehling solution test: It is generally used for reducing sugars and composed of two solutions, which are mixed in situ. Fehling solution A composed of $0.5 \%$ of copper sulphate whereas Fehling solution B composed of Sodium Potassium Tartarate.

Equal volumes of Fehling A and Fehling B solutions were mixed (1 ml each) and $2 \mathrm{ml}$ of aqueous solution of drug was added followed by boiling for 5-10 minutes on water bath.

\section{Tests for Alkaloids:}

Mayer's reagent test

Dragondroff's reagent test

Wagner's Test

Hager's Test

Mayer's reagent test: $2 \mathrm{ml}$ of test Solution was taken in a test tube to which and $2 \mathrm{ml}$ of the Mayer's reagent (Potassium Mercury Iodide solution) was added. A White or Pale-Yellow precipitate if formed indicated presence of Alkaloids except with Alkaloids of the $\mathrm{Pu}$ rine groups and few others.

Dragondroff's reagent test: $2 \mathrm{ml}$ of test Solution was taken in a test tube in which $2 \mathrm{ml}$ of the Dragon Droff's reagent (Mixture of Potassium Iodide and Bismuth sub 
nitrate solution) was added. An orange precipitate if formed indicated presence of Alkaloids.

Wagner's Test: Drug solution + few drops of Wagner's reagent (dilute Iodine solution), formulation of reddish-brown precipitate.

Hager's Test: A saturated aqueous solution of picric acid was employed for this test. When the test filtrate was treated with this reagent, an orange yellow precipitate was obtained which indicates the presence of alkaloids.

\section{Test for Amino acids:}

Ninhydrin test: The Ninhydrin test is used to detect the presence of alpha-amino acids and proteins containing free amino groups. Protein solution when heated with ninhydrin molecules, it gives characteristic deep blue or pale yellow colour due to the formation of complex between two ninhydrin molecule and nitrogen of free amino acid.

\section{Tests for Proteins:}

\section{Biuret test}

\section{Xanthoprotic test}

\section{Millons test}

Biuret test: A few $\mathrm{mg}$ of the residue was taken in water and $1 \mathrm{ml}$ of $4 \%$ sodium hydroxide solution was added to it, followed by a drop of $1 \%$ solution of copper sulphate. Development of violet or pink colour indicates the presence of proteins.

Xanthoprotic test: A small quantity of test sample was taken with $2 \mathrm{ml}$ of water and $0.5 \mathrm{ml}$ of concentrated nitric acid was added to it. Development of yellow colour indicates the presence of proteins.

Millons test: A small quantity of test sample was taken and 2 to $3 \mathrm{ml}$ of millons reagent was added. The white precipitate slowly turning to pink, indicate the presence of proteins.

\section{Test for saponin:}

Foam test: A small quantity of the test sample was taken in a test tube and shaken vigorously with a small amount of sodium bicarbonate and water. A stable, characteristic honeycomb like froth indicates the presence of saponins.

\section{Test for glycosides:}

\section{Borntragor's Test}

$1 \mathrm{ml}$ of Benzene and $0.5 \mathrm{ml}$ of dilute ammonia solution was added to the ethanolic extract and was observed for the formation of reddish pink colour.

\section{Test for Phenolic Compound}

The extract was taken in water and warmed; to this 2 $\mathrm{ml}$ of ferric chloride solution was added and observed for the formation of green and blue colour.

\section{Test for Flavonoids:}

Shinods test: A small quantity of test sample was dissolved in $5 \mathrm{ml}$ ethanol $(95 \% \mathrm{v} / \mathrm{v})$ and reacted with few drops of concentrated hydrochloric acid and $0.5 \mathrm{gm}$ of magnesium metal. Appearance of pink, crimson or magenta colour within a minute or two indicates the presence of flavonoids.

\section{Test for Steroids:}

Salkoweski reaction: Few mg of extract was taken in $2 \mathrm{ml}$ of chloroform and $2 \mathrm{ml}$ of concentrated sulphuric acid was added from the side of test tube. The test tube was shaken for few minutes. The development of red colour indicates the presence of steroids.

\section{Test for Tannins:}

Ferric chloride solution

Lead acetate

Pot. Dichromate

\section{$>$ Ferric chloride solution:}

A 5 percent solution of ferric chloride in $90 \%$ alcohol was prepared. Few drops of this solution were added to a little of the above filtrate. Appearance of dark green or deep blue colour indicates the presence of tannins.

Lead acetate: A 10 percent w/v solution of basic lead acetate in distilled water was added to the test filtrate. Development of precipitate indicates the presence of tannins.

> Pot. Dichromate: A solution of potassium dichromate was added to the filtrate. Appearance of dark colour indicates the presence of tannins.

Thin Layer Chromatography: ${ }^{9}$

T.L.C. plate coated with $0.25 \mathrm{~mm}$ layer of silica gel 60 $\mathrm{F}_{254}$ with fluorescent indicator, (Mercks) were used. Each plate having dimension $10 \mathrm{~cm}$ long and $2 \mathrm{~cm}$ width. 
Activation of pre-coated silica gel $60 \mathbf{F}_{\mathbf{2 5 4}}$

Plates were dried in hot oven at $105^{\circ} \mathrm{c}$ for one and half hour.

Preparation Mobile solution

Aamra: n-Butanol: Acidic acid: water (4:1:5

\section{RESULTS AND DISCUSSION}

In the present study of Mangifera Indica Linn was evaluated for its physicochemical and phytochemical aspects. Organoleptic parameters revealed that the powder of fruit of are brown in colour, with the characteristics odour, astringent and bitter in taste. The results of preliminary phytochemical analysis in the aqueous and alcoholic extracts of the drugs showed the presence of carbohydrates, amino acid, protein, steroids, alkaloids, saponins and tannins. (Table2)

\section{Mangifera indica Linn.}

Fig.1: Fresh fruit Fig.2: Bheeja powder

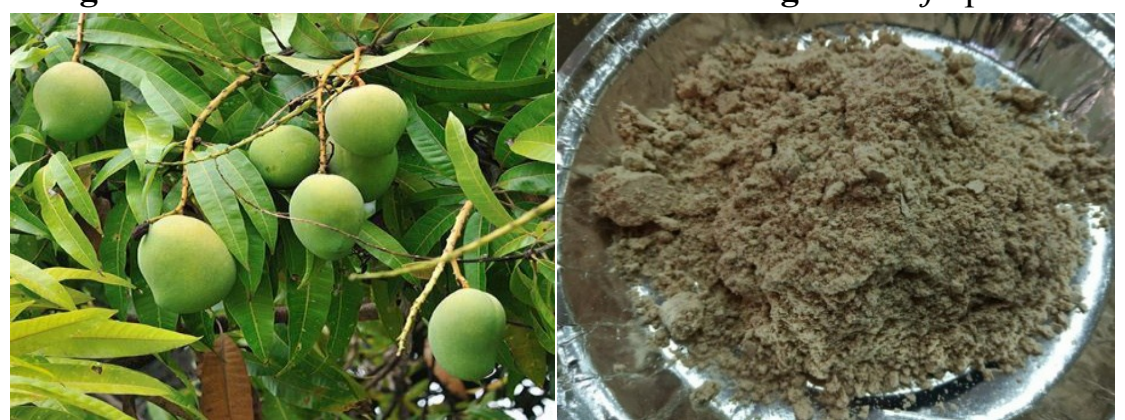

Table 1: Showing organoleptic examination of Aamra Mangifera indica Linn

\begin{tabular}{|r|l|l|}
\hline S. No & Organoleptic & Observation \\
\hline 1. & Colour & Light ivory \\
\hline 2. & Odour & Characteristics \\
\hline 3. & Taste & Bitter \\
\hline
\end{tabular}

Table 2: Showing powder microscopy of Beeja powder of Aamra Mangifera indica Linn

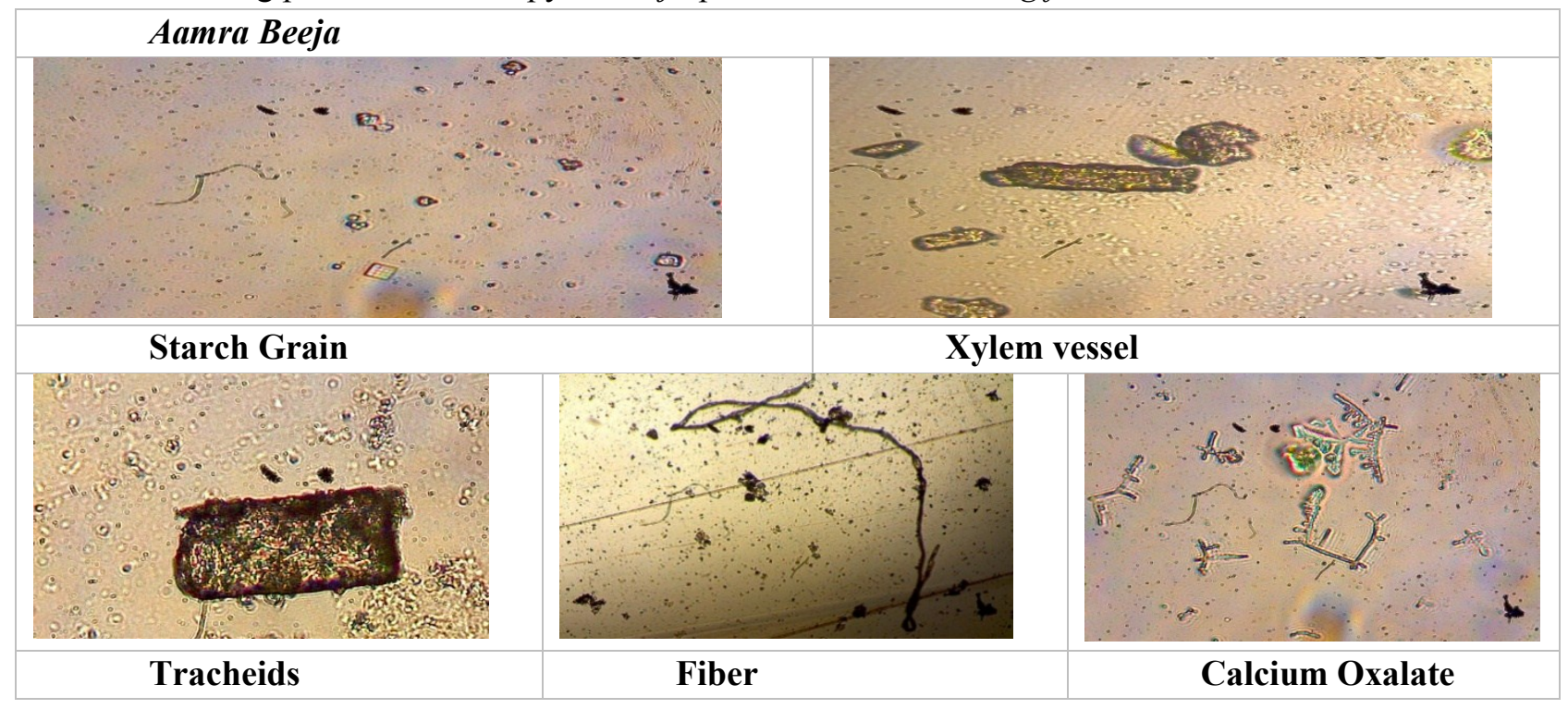


Table 3: Physico-chemical analysis of Aamra Mangifera indicaLinn.

\begin{tabular}{|l|l|l|}
\hline Sr.no. & Parameters & \multicolumn{1}{|c|}{ Results } \\
\hline 1. & Moisture content & $10.25 \%$ \\
\hline 2. & Aqueous extractive value & $14.67 \%$ \\
\hline 3. & Alcoholic extractive value & $12.98 \%$ \\
\hline 4. & Total ash & $2.12 \%$ \\
\hline 5. & Acid insoluble ash & $0.3 \%$ \\
\hline 6. & Water soluble ash & $1.45 \%$ \\
\hline
\end{tabular}

Table 4: Qualitative phytochemical tests of extracts of Aamra Mangifera Indica Linn.

\section{Carbohydrates}

\begin{tabular}{|c|c|c|c|}
\hline Sr. No. & Name of Test & Aqueous Extract & Alcohol Extract \\
\hline A. & Molisch test & $+\mathrm{ve}$ & $+\mathrm{ve}$ \\
\hline B. & Benedict test & $+\mathrm{ve}$ & -ve \\
\hline $\mathrm{C}$. & Fehling test & $+\mathrm{ve}$ & $+\mathrm{ve}$ \\
\hline 2. & Amino acids & & \\
\hline A. & Ninhydrine test & $+\mathrm{ve}$ & -ve \\
\hline 3. & Protein & & \\
\hline A. & Biuret test & $+\mathrm{ve}$ & -ve \\
\hline B. & Xanthoprotic test & $+\mathrm{ve}$ & -ve \\
\hline C. & Millon's test & $+\mathrm{ve}$ & $+\mathrm{ve}$ \\
\hline 4. & Alkaloids & & \\
\hline A. & Dragondrof test & $+\mathrm{ve}$ & +ve \\
\hline B. & Wagner's test & $+\mathrm{ve}$ & $+\mathrm{ve}$ \\
\hline C. & Hager's test & -ve & -ve \\
\hline 5. & Saponin & & \\
\hline \multirow[t]{2}{*}{ A. } & Foam test & $+\mathrm{ve}$ & -ve \\
\hline & Glycosides & & \\
\hline A. & Borntragor's test & -ve & -ve \\
\hline 7. & Phenolic Compound & & \\
\hline A. & Phenolic Compound test & -ve & $+\mathrm{ve}$ \\
\hline 8. & Steroids & & \\
\hline A. & Salkowaski reaction & $+\mathrm{ve}$ & -ve \\
\hline 9. & Tannins & & \\
\hline A. & $\mathrm{Fecl}_{3}$ test & -ve & +ve \\
\hline B & Lead acetate & -ve & -ve \\
\hline $\mathrm{C}$ & Pot. Dichromate & $+\mathrm{ve}$ & -ve \\
\hline
\end{tabular}

\section{Thin Layer Chromatography:}

Thin layer Chromatography is a tool for separation and identification of chemical constituent present in the herb or chemical mixtures with mobile solution Toluene: Ethyl acetate 7:3. Alcoholic extracts of fruit Aamra Rf. Value: 0.37, 0.63, 0.82, 0.89, 0.92, 0. 95.

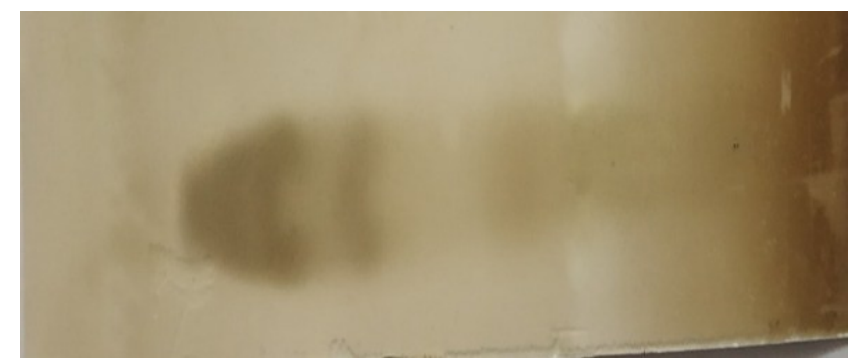




\section{CONCLUSION}

Physico-chemical parameters such as moisture content, total ash, acid insoluble ash, water soluble ash, water soluble extractive value and alcoholic soluble extractive value were observed. The phytochemical analysis confirmed the presence of various phytochemical constituents such as carbohydrates, amino acid, protein, alkaloids, saponins, glycosides steroids and tannins. These values can be useful to detect adulteration. All studies standardization parameters like physicochemical and phytochemical screening parameters provide the knowledge in the identification, authentication of kernel of Mangifera Indica Linn.

\section{REFERENCES}

1. Sharma P.V, Naama Rupajnaanam Satyapriya Prakashan Varanasi; Reprint ed 2015; Page no 25-26.

2. Anonymous. The Ayurvedic Pharmacopoeia of India, VolI. Part-I 1st ed. Dept. of I.S.M. and H. Ministry of Health and Family Welfare, Govt. of India; 2001, Page no-21

3. Database 2 Sharma PC, Yelne MB, Dennis TJ. Database on Medicinal Plants used in Ayurveda, Vol. 2. New Delhi: C.C.R.A.S, Dept. of I.S.M. \& H., Ministry of Health and Family Welfare, Govt. of India; 2001, page no. 10 .

4. Database 2 Sharma PC, Yelne MB, Dennis TJ. Database on Medicinal Plants used in Ayurveda, Vol. 2. New Delhi: C.C.R.A.S, Dept. of I.S.M. \& H., Ministry of Health and Family Welfare, Govt. of India; 2001, 8.

5. Manual of method of analysis of food, food safety and standard authority of India Ministry of Health and Family Welfare, Govt. of India, New Delhi 2015.

6. Laboratory guide for the analysis of Ayurveda and Siddha formulations, CCRAS, Dept. of Ayush, Ministry of Health and Family Welfare, Govt. Of India, New Delhi p.27.

7. Laboratory guide for the analysis of Ayurveda and Siddha formulations, CCRAS, Dept. of Ayush, Ministry of Health and Family Welfare, Govt. Of India, New Delhi p.27.

8. Laboratory guide for the analysis of Ayurveda and Siddha formulations, CCRAS, Dept. of Ayush, Ministry of Health and Family Welfare, Govt. Of India, New Delhi p.83-87.

9. Laboratory guide for the analysis of Ayurveda and Siddha formulations, CCRAS, Dept. of Ayush, Ministry of
Health and Family Welfare, Govt. Of India, New Delhi p.89-92.

\section{Source of Support: Nil \\ Conflict of Interest: None Declared}

How to cite this URL: Pooja Dogra et al: Physicochemical And Phytochemical Analysis Of Aamra (Mangifera Indica Linn.. International Ayurvedic Medical Journal \{online\} 2020 \{cited July, 2020\} Available from: http://www.iamj.in/posts/images/upload/2394 2400.pdf 